\title{
Factors Affecting the Production of Succinoyl Trehalose Lipids by Rhodococcus erythropolis SD-74 Grown on $n$-Alkanes
}

\author{
Yasukazu Uchida, Satoru Misawa, * Tadaatsu NaKahara \\ and Takeshi TABUCHI \\ Institute of Applied Biochemistry, University of Tsukuba, \\ Tsukuba, Ibaraki 305, Japan \\ Received October 5, 1988
}

\begin{abstract}
Factors affecting the extracellular production of succinoyl trehalose lipids by Rhodococcus erythropolis SD-74 were studied to optimize the culture conditions for the maximum production. Since the optimal $\mathrm{pH}$ for the production of the acidic exolipid was about 7 , the addition of phosphate buffer (pH 7) of high concentrations $(0.3$ to $0.4 \mathrm{M}$ ) to shake culture media was essential for exolipid production. A high osmotic equivalent of culture broth (about $2 \% \mathrm{NaCl}$ equivalent value) was favorable for exolipid production. Although $\mathrm{K}^{+}$was superior to $\mathrm{Na}^{+}$, chlorides at higher concentrations were more inhibitory for exolipid production compared to sulfates or phosphates. Under the optimal conditions in a jar fermentor, the concentration of the exolipid in the culture broth reached about $40 \mathrm{~g} / \mathrm{I}$ after 10 days.
\end{abstract}

In the preceding paper, ${ }^{1)}$ we reported that Rhodococcus erythropolis SD-74 abundantly produced acidic exolipids, succinoyl trehalose lipids, from $n$-hexadecane, and that the two main components of the exolipid were $2,3,4,2^{\prime}$ di- $O$-succinoyl-di- $O$-alkanoyl- $\left(\mathrm{C}_{16} \quad 87 \%, \mathrm{C}_{14}\right.$ $13 \%$ )-trehalose (STL-1) and 2,3,4-mono- $O$ succinoyl-di- $O$-alkanoyl- $\left(\mathrm{C}_{16} 75 \%, \mathrm{C}_{14} 25 \%\right)$ trehalose (STL-2). Ristau and Wagner ${ }^{2)}$ reported that $R$. erythropolis DSM 43245 produced another exolipid, 2,3,4,2'-mono- $O$-succinoyl-tri- $O$-alkanoyl- $\left(2 \times \mathrm{C}_{10}, \quad 1 \times \mathrm{C}_{8}\right)$-trehalose, in a small amount. Wagner et al. ${ }^{3)}$ reported that the latter exolipid had good surfactant properties in the presence of high salt concentrations and that it was produced in an increased amount $(7.9 \mathrm{~g} / 1)$ with a temperature shift from 30 to $21^{\circ} \mathrm{C}$ at the late stage and nitrogen limitation. The significance of biosurfactants was recently reviewed by Rosenberg. $\left.{ }^{4}\right)$ This paper describes experiments designed to determine factors leading to maximal production of the exolipid by $R$. erythropolis SD74.

\section{Materials and Methods}

Microorganism. Strain SD-74, used exclusively in this study, was isolated from a soil sample at Sado Island and identified tentatively as Rhodococcus erythropolis in the preceding study."

Media and culture conditions. The seed culture medium used was the same as described in the preceding paper. ${ }^{1 /}$ The following four basal fermentation media contained $10 \%$ (v/v) $n$-hexadecane, $0.3 \% \mathrm{KNO}_{3}, 0.01 \% \mathrm{MgSO}_{4}$. $7 \mathrm{H}_{2} \mathrm{O}, 0.1 \%$ yeast extract (except for medium-D), tap water and potassium phosphate buffer $(\mathrm{pH} \mathrm{7.0)}$ of different concentrations: medium-A with $0.01 \mathrm{M}$ potassium phosphate buffer; medium-B with $0.1 \mathrm{M}$ buffer; medium-C with $0.3 \mathrm{M}$ buffer; and the optimized medium-D with $0.3 \mathrm{M}$ buffer and an increased amount of yeast extract $(0.3 \%)$. All inorganic salts used were of guaranteed reagent grade (Wako Pure Chemical Industries, Ltd.). Several ingredients were changed, as indicated in the text and legends.

Seed cultures were prepared as described previously. ${ }^{11}$ The seed cultures $(2 \mathrm{ml})$ were transferred to $300-\mathrm{ml}$ Erlenmeyer flasks containing $30 \mathrm{ml}$ of the basal fermentation media. The flasks were shaken at $30^{\circ} \mathrm{C}$ for 7 days on a rotary shaker $(220 \mathrm{rpm})$. Fermentor experiments were performed in a 51 Waldhof type jar fermentor (Marubishi model MD-300) with the following culture conditions:

* Present address: Nippon Mining Co., Ltd., Niizominami, Saitama 335, Japan. 
incubation temperature, $30^{\circ} \mathrm{C}$; agitation, $600 \mathrm{rpm}$; and aeration, $1 \mathrm{v} / \mathrm{v} / \mathrm{min}$. The seed culture $(200 \mathrm{ml})$ was inoculated into the jar fermentor containing 31 of different fermentation media. The $\mathrm{pH}$ was automatically maintained at 7.0 with $5 \mathrm{~N} \mathrm{KOH}$.

Analytical methods. The total exolipid concentration was estimated by the anthrone method. ${ }^{5)}$ The culture broths (whole in flasks or $30 \mathrm{ml}$ ) were acidified with $3 \mathrm{~N}$ $\mathrm{H}_{2} \mathrm{SO}_{4}$ to $\mathrm{pH} 3$ and then shaken with ethyl acetate $(30 \mathrm{ml})$ to extract the total exolipid. After standing, the solvent layer was removed and a $20 \mu$ l aliquot of it was analyzed by the anthrone method. The optical density was measured at $625 \mathrm{~nm}$ with a Spectrophotometer 100-10 (Hitachi Ltd.). A mixture of succinoyl trehalose lipids-1 and -2, prepared as described previously, ${ }^{11}$ was used as the standard.

The ethyl acetate layer $(5 \mathrm{ml})$ was concentrated under reduced pressure and the resultant residue was extracted twice with $n$-hexane. The combined $n$-hexane extracts were used to estimate the concentration of remaining $n$ hexadecane by gas-chromatography. The gas-chromatography was performed with a Shimadzu Gas Chromatograph GC-8A equipped with a flame-ionization detector. Separations were performed on a glass column $(4 \mathrm{~mm} \times 1 \mathrm{~m})$ packed with $15 \%$ FFAP on Chromosorb WAW at $150^{\circ} \mathrm{C}$. $n$-Heptadecane was used as the internal standard.

Cell growth was measured as dry cell weight, after the remaining water layer in the preceding extraction had been centrifuged, washed with ethyl acetate and $50 \%$ methanol, and then dried overnight at $105^{\circ} \mathrm{C}$.

\section{Results and Discussion}

\section{Effect of the n-hexadecane concentration}

Preliminary experiments showed that strain SD-74 was apt to form cell-clumps in shake cultures, which caused the exolipid yield to decrease. The formation of clumps was avoided and reproducible experimental results were obtained with the use of a fairly high initial concentration of $n$-hexadecane $(10 \%$, $\mathrm{v} / \mathrm{v})$. Concentrations of more than $10 \%$, however, caused a decrease in the yield of the exolipid. The concentration of $10 \%$, accordingly, was used throughout the present study.

The strain was able to grow well on fructose and glycerol, and moderately on glucose, but unable to produce exolipids from these carbohydrates.

Since the exolipid contains trehalose and succinate moieties, the effect of the supplementation of different carbon sources on exolipid production was examined in medium-B supplemented with fructose, glycerol, glucose, citrate or succinate, at concentrations of 2 to $4 \%$. The supplementation of these different carbon sources failed to give substantial increases in exolipid production.

Exolipid productivity from different $n$ alkanes and other noncarbohydrate carbon sources will be described elsewhere.

\section{Effect of the initial $p H$}

Maintenance of the culture broth at neutral $\mathrm{pH}$ was observed to be important for pro-

Table I. EfFect of pH on Exolipid Production

\begin{tabular}{cccc}
\hline $\begin{array}{c}\text { Initial } \\
\mathrm{pH}\end{array}$ & $\begin{array}{c}\text { Final } \\
\mathrm{pH}\end{array}$ & $\begin{array}{c}\text { Dry cell } \\
\text { weight } \\
(\mathrm{mg} / \mathrm{ml})\end{array}$ & $\begin{array}{c}\text { Exolipid } \\
(\mathrm{mg} / \mathrm{ml})\end{array}$ \\
\hline 5.60 & 5.32 & 6.2 & 10.1 \\
6.04 & 5.68 & 7.0 & 14.7 \\
6.28 & 5.92 & 7.5 & 17.8 \\
6.50 & 6.22 & 7.8 & 19.7 \\
6.76 & 6.53 & 8.0 & 21.4 \\
7.00 & 6.83 & 8.3 & 21.8 \\
7.25 & 7.10 & 8.5 & 19.8 \\
7.45 & 7.26 & 8.6 & 18.3 \\
7.95 & 7.72 & 7.6 & 13.0 \\
\hline
\end{tabular}

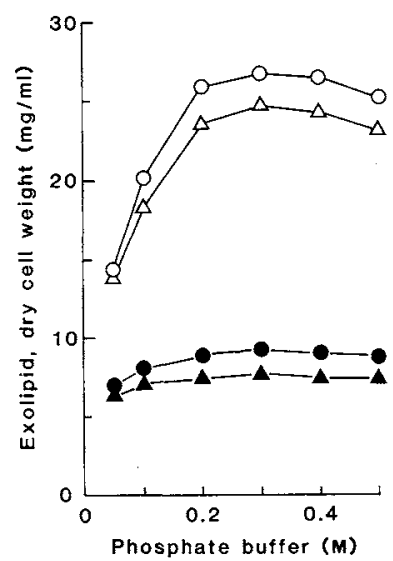

Fig. 1. Effect of the Concentration of the Phosphate Buffer on Exolipid Production.

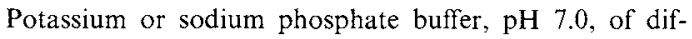
ferent concentrations was added to medium-A containing $0.01 \mathrm{M}$ phosphate buffer. $\mathrm{O}-\mathrm{O}$, exolipid in potassium phosphate buffer; $\triangle-\triangle$, exolipid in sodium phosphate buffer; - dry cell weight in potassium phosphate buffer; $\boldsymbol{\Lambda}-\boldsymbol{\Delta}$, dry cell weight in sodium phosphate buffer. 
duction of the acidic exolipid. The addition of excess $\mathrm{CaCO}_{3}$ to medium-A, however, did not maintain a neutral $\mathrm{pH}$ or improve the production.

Table I shows the effect of the initial $\mathrm{pH}$ on exolipid production in medium- $\mathrm{C}$, which was further supplemented with 0.1 м 1,2,3-propanetricarboxylate and adjusted to different $\mathrm{pHs}$ with $4 \mathrm{~N} \mathrm{H}_{2} \mathrm{SO}_{4}$ or $2 \mathrm{~N} \mathrm{NaOH}$. In all the culture broths buffered with $0.3 \mathrm{M}$ phosphate and $0.1 \mathrm{M}$ 1,2,3-propanetricarboxylate, the $\mathrm{pH}$ dropped considerably after 5 days cultivation, because of accumulation of the acidic exolipid.

The optimal $\mathrm{pH}$ for exolipid production was determined to be 6.5 to 7.0 ; this value was slightly lower than the optimum for cell growth (7.0 to 7.5$){ }^{1 \text { ) }}$

\section{Effect of the phosphate buffer concenration}

Figure 1 shows the effects of the addition of sodium or potassium phosphate buffer $(\mathrm{pH}$ 7.0) of different concentrations to medium-A, which contained phosphate buffer of a low concentration $(0.01 \mathrm{M})$ initially, on exolipid production. The addition of higher than $0.3 \mathrm{M}$ phosphate buffer improved the exolipid production, but this stimulatory effect of the buffers, of high concentrations, was more marked with potassium phosphate, compared with sodium phosphate.

\section{Effects of the addition of different salts}

Potassium phosphate buffer was found to be superior to sodium phosphate buffer for exolipid production. Consequently, the effect of the addition of $\mathrm{K}^{+}$or $\mathrm{Na}^{+}$as the chloride or sulfate at high concentrations on exolipid production was examined in medium-B, which contained phosphate buffer $(0.1 \mathrm{M})$ of a moderate concentration. The addition of these salts gave marked increases in exolipid production (Fig. 2). The optimal concentrations for exolipid production, however, varied when they were expressed in \% and M. Therefore, in the figure, the osmotic equivalents of culture broths are conveniently expressed in terms of the total $\mathrm{NaCl}$ equivalent values. ${ }^{6)}$ The figure also shows the effect of the concentration of

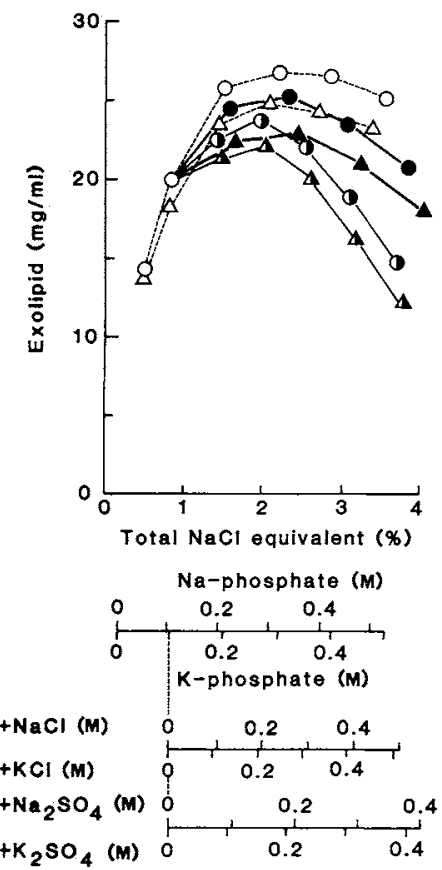

Fig. 2. Effects of the Addition of Different Salts on Exolipid Production.

Different salts were added to medium-B containing $0.1 \mathrm{M}$ phosphate buffer. The salt concentrations are conveniently expressed in terms of total $\mathrm{NaCl}$ equivalent values ${ }^{6)}$ of culture broths. $-\mathrm{KCl} ; \boldsymbol{\Lambda}-\boldsymbol{\Delta}, \mathrm{NaCl}$;

$\mathrm{K}_{2} \mathrm{SO}_{4} ; \boldsymbol{\Delta}-\boldsymbol{\Delta}, \mathrm{Na}_{2} \mathrm{SO}_{4} ; \mathrm{O}--\mathrm{O}$, potassium phosphate buffer, see Fig. I; $\triangle{ }^{--} \triangle$, sodium phosphate buffer, see Fig. 1.

the phosphate buffer shown in Fig. 1, as dotted lines. The results indicated that an osmotic equivalent corresponding to an $\mathrm{NaCl}$ equivalent value of about $2 \%$ was favorable for exolipid production, and that $\mathrm{K}^{+}$was superior to $\mathrm{Na}^{+}$. At higher concentrations, chlorides were more inhibitory for exolipid production, compared with sulfates or phosphates, although cell growth was almost completely unaffected. Media-C and -D had good osmotic equivalents corresponding to about $2 \% \mathrm{NaCl}$ equivalent values.

In order to increase the osmotic equivalent of the culture broth, the effect of the addition of $\mathrm{CaCl}_{2}$ or $\mathrm{MgCl}_{2}$ was examined. Cell-clumps were abundantly observed in these cultures and exolipid production was repressed even with a concentration of $0.02 \mathrm{M}$. 
The omission of $\mathrm{MgSO}_{4} \cdot 7 \mathrm{H}_{2} \mathrm{O}$ from the optimized medium-D resulted in a decrease in the exolipid yield (about 10\%), but at concentrations ranging from 0.005 to $0.02 \%$, the yield remained unchanged.

\section{Effects of the addition of metal ions}

In the cultures shown in Figs. 1and 2, the respective salts, even though all were of guaranteed reagent grade, were added at extremely high concentrations, thus, the stimulatory or inhibitory effects of these salts on exolipid production might be ascribable in part to metal ions contaminating the salts as impurities. The addition of $\mathrm{FeSO}_{4} \cdot 7 \mathrm{H}_{2} \mathrm{O}$ at concentrations of 0.5 to $5 \mathrm{mg} / \mathrm{ml}$ to medium-C increased exolipid production to about $5 \%$. The addition of $\mathrm{MnCl}_{2} \cdot 4 \mathrm{H}_{2} \mathrm{O}, \mathrm{ZnSO}_{4} \cdot 7 \mathrm{H}_{2} \mathrm{O}$ or $\mathrm{CuSO}_{4} \cdot 5 \mathrm{H}_{2} \mathrm{O}$ at a low concentration $(0.5$ $\mathrm{mg} / \mathrm{ml}$ ) decreased the exolipid yield slightly, while $\mathrm{CoCl}_{2} \cdot 6 \mathrm{H}_{2} \mathrm{O}$ decreased it to about one-half.

\section{Effects on nitrogen sources}

The effects of different nitrogen sources, instead of $\mathrm{KNO}_{3}$ in medium-C, on exolipid production were examined at the same concentration, $0.03 \mathrm{M}$, as nitrogen. Exolipid production and cell growth were almost completely unaffected by $\left(\mathrm{NH}_{4}\right)_{2} \mathrm{SO}_{4}, \mathrm{NH}_{4} \mathrm{H}_{2} \mathrm{PO}_{4}$,

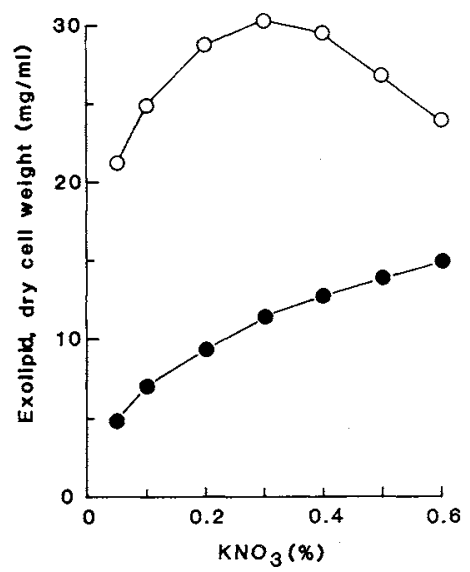

Fig. 3. Effect of the Concentration of Potassium Nitrate on Exolipid Production.

The concentration was varied in the optimized medium-D. $\mathrm{O}-\mathrm{O}$, exolipid;

, dry cell weight.
$\mathrm{NH}_{4} \mathrm{NO}_{3}$ or urea, all of which were sterilized separately. Polypepton applied at concentrations of 0.4 and $0.6 \%$ gave about 55 and $70 \%$ exolipid yields, respectively, compared with those obtained with other nitrogen sources. Accordingly, $\mathrm{KNO}_{3}$ was selected as the nitrogen source in the basal media, because its separate sterilization was not required.

Figure 3 shows the effect of the concentration of $\mathrm{KNO}_{3}$ in medium-D. A better yield

Table II. Effects of Different Supplementary

Organic Nutrients on ExOlipid Production

\begin{tabular}{cccc}
\hline \multicolumn{1}{c}{ Nutrient } & & $\begin{array}{c}\text { Dry cell } \\
\text { weight }\end{array}$ & $\begin{array}{c}\text { Exolipid } \\
(\mathrm{mg} / \mathrm{ml})\end{array}$ \\
\hline None & & 5.9 & 20.2 \\
Casamino acid & 0.1 & 7.9 & 23.8 \\
(Difco) & 0.2 & 8.4 & 24.7 \\
Beef extract & 0.1 & 7.4 & 23.5 \\
(Difco) & 0.2 & 7.9 & 24.2 \\
Polypepton & 0.1 & 7.3 & 20.6 \\
& 0.2 & 7.5 & 20.8 \\
Rice bran & 0.1 & 7.6 & 23.5 \\
& 0.2 & 8.0 & 24.4 \\
Corn steep liquor & 0.1 & 8.1 & 23.3 \\
Yeast extract & 0.2 & 8.8 & 23.9 \\
(Oriental) & 0.05 & 7.2 & 24.6 \\
& 0.1 & 8.7 & 26.4 \\
& 0.2 & 9.9 & 28.2 \\
& 0.3 & 11.4 & 29.7 \\
& 0.4 & 12.3 & 28.4 \\
& 0.5 & 13.5 & 26.3 \\
\hline (O) & & &
\end{tabular}

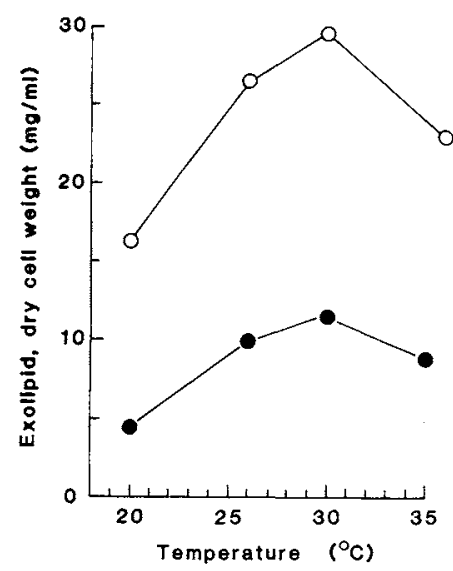

Fig. 4. Effect of Temperature on Exolipid Production.

The strain was cultured in the optimized medium-D. $\mathrm{O}-\mathrm{O}$, exolipid; , dry cell weight. 


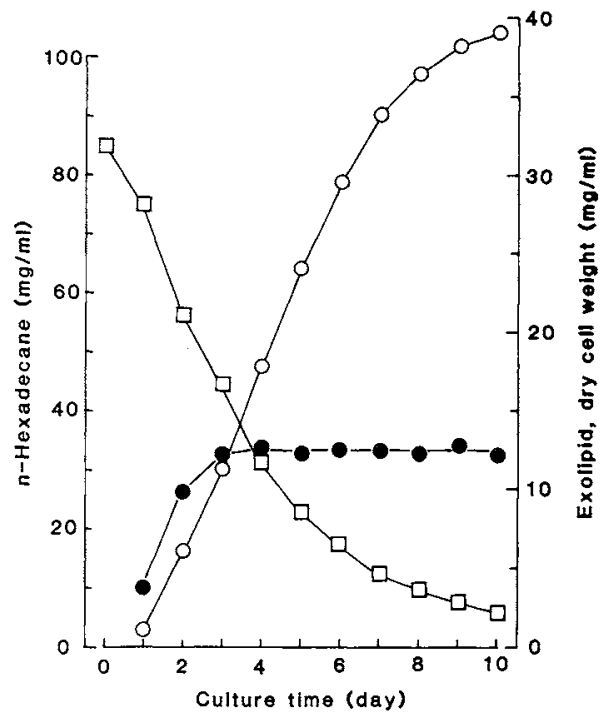

Fig. 5. Time Course of Exolipid Production in a 5-1 Jar Fermentor.

The strain was cultured in the optimized medium- $D$. $\bigcirc-\bigcirc$, exolipid; $-\bigcirc$, dry cell weight; $\square-\square$, residual $n$-hexadecane.

was observed at about $0.3 \%$. Ristau and Wagner, ${ }^{2)}$ and Wagner et al. ${ }^{3)}$ reported that $R$. erythropolis DMS 43215 produced the trehalose lipid mainly under nitrogen limited conditions $\left(0.1 \%\left(\mathrm{NH}_{4}\right)_{2} \mathrm{SO}_{4}\right)$.

\section{Effects of the addition of supplementary organic nutrients}

As Table II shows, all the tested supplementary nutrients stimulated exolipid production as well as cell growth, yeast extract being the most effective. From these results, the optimized medium-D containing $0.3 \%$ yeast extract was selected.

\section{Effects of temperature and aeration}

As Fig. 4 shows, $30^{\circ} \mathrm{C}$ was found to be optimum for exolipid production. On the contrary, Wagner et al. ${ }^{3)}$ reported that $R$. erythropolis DMS 43215 produced the trehalose lipid more abundantly at 21 than $30^{\circ} \mathrm{C}$.

Different volumes $(25 \sim 120 \mathrm{ml})$ of mediumD were put into $300-\mathrm{ml}$ Erlenmeyer flasks to examine the effect of aeration on exolipid production. Volumes of 30 and $40 \mathrm{ml}$ medium gave higher concentrations of the exolipid, but a larger volume, $120 \mathrm{ml}$, caused a decrease to about one-half concentration.

\section{Time course of exolipid production in a Waldhof} type jar fermentor

Figure 5 shows a typical time course of exolipid production in medium-D when the $\mathrm{pH}$ was automatically controlled at 7.0 with $5 \mathrm{~N} \mathrm{KOH}$. The fermentation was apparently nongrowth associated. After incubation for 10 days, the exolipid concentration reached about $40 \mathrm{mg} / \mathrm{ml}$; this value corresponded to an about $50 \%$ yeidld on the weight basis of $n$-hexadecane consumed.

A similar high yield of the exolipid was obtained in modified medium-D, which contained $0.15 \mathrm{M} \mathrm{K}_{2} \mathrm{SO}_{4}$ and $0.1 \mathrm{M}$ phosphate buffer, instead of $0.3 \mathrm{M}$ buffer. Medium-A, having a low $\mathrm{NaCl}$ equivalent value, gave a low yield of the exolipid $(15 \mathrm{mg} / \mathrm{ml})$ after 10 days, even with automatic control of the $\mathrm{pH}$.

Acknowledgments. We wish to thank K. Sakai and K. Sugawara for their technical assistance. This work was supported by a Grant-in-Aid for Scientific Research from the Ministry of Education, Science and Culture of Japan.

\section{References}

1) Y. Uchida, R. Tsuchiya, M. Chino, J. Hirano and T. Tabuchi, Agric. Biol. Chem., 53, 757 (1989).

2) E. Ristau and F. Wagner, Biotechnol. Lett., 5, 95 (1983).

3) F. Wagner, J. S. Kim, S. Lang, Z. Y. Li, G. Marwede, U. Matulovic, E. Ristau and C. Syldatk, Proceedings, 3rd European Congress on Biotechnology, Vol. 1, München, September, 1984, p. 3.

4) E. Rosenberg, CRC Crit. Rev. Biotechnol., 3, 109 (1986).

5) J. E. Hodge and B. T. Hofreiter, "Methods in Carbohydrate Chemistry," Vol. 1, ed. by R. L. Whistler and M. L. Wolfrom, Academic Press, New York, 1962, pp. 389 390.

6) "The Merck Index" 10th Ed., ed. by M. Windholz, S. Budavain, R. F. Blumetti and E. S. Ottervein, Merck \& Co., Inc., Rahway, N. J., 1983, MISC-47 -69. 